\title{
JANUS ON KULTAA
}

\section{Pääkirjoitus}

\section{0}

Janus, kuten muutkin journal.fi-alustalla julkaistavat lehdet ovat avoimesti kaikkien saatavilla. Hankekielellä kyse on kultaisesta avoimen julkaisemisen tyypistä. Vihreä julkaiseminen taas tarkoittaa sitä, että kirjoittajan julkaisukanavalle lähettämä viimeinen tekstiversio ennen taittoa rinnakkaisjulkaistaan. Rinnakkaisjulkaisu tallennetaan yleensä kirjoittajien omien organisaatioiden järjestelmiin ja se voi olla julkaisevan lehden politiikan mukaisesti saatavilla joko heti tai viiveellä.

Avoin tiedejulkaiseminen on tärkeää, mutta saattaa vaikeuttaa lehtien taloudellista tilannetta, sillä avoin julkaiseminen vie suuren osan lehtien tilaajista, varsinkin institutionaaliset tilaajat, kuten kirjastot. Tieteen avoimen saatavuuden merkitys on kasvanut, kun yhteiskunnallisen keskustelun luonne on muuttunut. Puhutaan totuuden jälkeisestä ajasta, jolloin on entistä tavallisempaa ja ehkä hyväksyttävämpää esittää julkisuudessa epätosia väitteitä ja pyrkiä siten vaikuttamaan yleiseen mielipiteeseen tai vaikka äänestyskäyttäytymiseen. Toinen keskustelun luonnetta kuvaava ilmiö on kertomusten käyttö sanoman perusteluna ja vahvistamisena. Poliittisia päätöksïa voidaan perustella kertomalla, miten juuri tietynlaisessa tilanteessa olevan henkilön elämä muuttuu paremmaksi tämän politiikkamuutoksen johdosta.Yksilöllinen kokemus yleistetään ja sitä käytetään moraalisena perusteluna päätökselle.

Tällaisessa maailmassa avoimesti saatavilla olevalle tieteelliselle tiedolle on erityisen suuri tarve. Juuri nyt uusi hallitus on käynnistämässä erilaisia sosiaali- ja terveydenhuollon uudistuksia. Sosiaaliturvaa uudistavaa parlamentaarista komiteaa, jonne jokainen eduskuntaryhmä nimittää edustajansa, ollaan helmikuussa 2020 kokoamassa. Komitean tehtävänä on esittää linjauksia suomalaisesta sosiaaliturvajärjestelmästä vuoteen 2027 mennessä. Tulevaisuuden sosiaali- ja terveyskeskus -ohjelmassa, jota ollaan myös käynnistämässä, on luvattu luoda ihmislähtöisiä palvelukokonaisuuksia ja kuunnella tarkasti ihmisten tarpeita.

Tässä vuoden 2020 Januksen ensimmäisessä numerossa julkaistut tutkimusartikkelit käsittelevät enimmäkseen juuri ihmisten tarpeita ja kokemuksia.Vaikka poliittiset päättäjät eivät juuri tieteellisiä tutkimusartikkeleita lue, paikalliset toimijat ja kehittämisessä mukana olevat tutkijat lukevat. Poliittisille päättäjille on tarpeen kirjoittaa lyhyitä ja selkeitä tiedotteita eri kanavia käyttäen. Tutkijoiden on tärkeä osallistua yhteiskunnalliseen keskusteluun monin eri tavoin. 
Tässä Januksen numerossa Hannariikka Linnavuori ja Elina Stenvall käsittelevät lasten ja nuorten vuoroasumista koskevaa päätöksentekoa melko harvinaisella laadullisella pitkittäisaineistolla. Lasten ja nuorten kannalta tärkeää vuoroasumisessa on se, että heidän toiveitaan kuunnellaan, mutta vastuuta päätöksestä ei kuitenkaan sysätä heille. Myös Anna Juntusen artikkelissa on huomioitu nuorten näkökulma sekä lisäksi ajallisuus. Hän tarkastelee nuorten toimijuuden tuntoa, joka on sisäinen kokemus valinnanmahdollisuuksista. Nuorella on monia erilaisia toimijuuksia tilanteesta riippuen ja niiden merkityksellistäminen voi vaihdella elämänkulun käännekohdissa.

Eeva Ekqvist ja Katja Kuusisto kääntävät lukijan katseen tulevaisuuteen tarkastelemalla aikuissosiaalityön asiakkaiden tulevaisuuden odotuksia asiakastyytyväisyyskyselyn avulla. Kävi ilmi, että mikäli saatu palvelu ei vastannut odotuksia, riski tulevaisuuteen epävarmasti suhtautumiseen oli suurempi kuin niillä, jotka kokivat saadun palvelun vastanneen heidän odotuksiaan. Kari Soronen tarkastelee tunteiden merkitystä kokemusasiantuntijuuden kehittymisessä. Tutkimuksen perusteella voidaan todeta, että kokemusasiantuntijaksi kehittymisessä käydään monia tunteita läpi ja ne voidaan esittää kuuden vaiheen kautta: tunteiden kaaos, erittely, hyväksyminen, jakaminen, luottamuksen vahvistuminen, sekä jatkaminen ja luopuminen.

Januksen toimitus on muuttanut Lapin yliopistoon Rovaniemelle. Kahden päätoimittajan lisäksi toimituskuntaan kuuluvat professori Sanna Hautala, tutkijatohtori Heikki Huilaja, yliopistonlehtori Ritva Linnakangas, joka vastaa puheenvuoroista, yliopistonlehtori Kati Kallinen, joka huolehtii kirja-arvioista ja toimitussihteeri, yliopistonlehtori Kati Kataja. Tämän lehden sisältö on vielä edellisen Itä-Suomen yliopiston toimituskunnan aikaansaannosta, samoin kuin Januksen pääsy Directory of Open Access Journals-rekisteriin (DOAJ). Tähän pääseminen on merkki laadukkaasta tiedejulkaisemisesta ja edellyttää, että Janus jatkaa korkeatasoisena, avoimesti saatavilla olevana tieteellisenä julkaisijana. Kiitämme edellisiä päätoimittajia Eeva Jokista ja Aini Pehkosta, toimitussihteeri Helena Hirvosta ja koko toimituskuntaa erinomaisesta työstä ja Januksen kehittämisestä. Tästä on uuden toimituskunnan hyvä aloittaa kolmevuotinen tehtävä tiedejulkaisemisen kentällä.

Marjo Romakkaniemi ja Minna Zechner 